\title{
Molluscicidal Activity of Compounds Isolated from Euphorbia conspicua N. E. Br.
}

\author{
Rosalina C. S. Mata, ${ }^{a}$ Dina I. M. D. de Mendonça, ${ }^{*, b}$ Liliana Vieira, ${ }^{b}$ \\ Aldenir F. dos Santos, ${ }^{c}$ Luciana A. da Silva, ${ }^{c}$ Jorge F. Gaspar, ${ }^{d}$ Célia Martins, ${ }^{d}$ \\ José Rueff ${ }^{d}$ and Antônio E. G. Sant'Ana ${ }^{c}$
}

${ }^{a}$ Chemistry Department, Agostinho Neto University, Luanda, Angola

${ }^{b}$ Textile and Paper Materials Center, University of Beira Interior, 6200-001 Covilhã, Portugal

${ }^{c}$ Chemistry Department, Federal University of Alagoas, 57092-970 Maceió-AL, Brazil

${ }^{d}$ Department of Genetics, Faculty of Medical Sciences, New University of Lisbon, Lisbon, Portugal

\begin{abstract}
O latex de Euphorbia conspicua foi fracionado nas frações triterpênica e irritantes I e II. Da fração triterpênica foram isolados 15 compostos já conhecidos e um novo triterpeno denominado $3 \beta$ - $(E)$-cinamoileuforbol. A fração irritante II forneceu o 20-O-acetil-3- $O$-angeloil-ingenol. A atividade moluscicida dos compostos eufol, $3 \beta$-acetoxieufa-8,24-dieno, $3 \beta$ - $(E)$-cinamoileuforbol e 20-O-acetil-3- $O$-angeloil-ingenol foi avaliada. O 20-O-acetil-3- $O$-angeloil-ingenol apresentou uma $\mathrm{LC}_{100}$ de $1 \mu \mathrm{g} \mathrm{mL}^{-1}$, a qual foi equivalente ao moluscicida padrão niclosamida. Os compostos

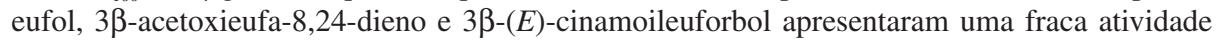
moluscicida. O $3 \beta$ - $(E)$-cinamoileuforbol foi submetido a testes de mutagenicidade (teste de Ames com TA 98, 100 e 102) na presença e ausência de ativação metabólica (mistura S9). Foram também realizados os ensaios de citotoxicidade (teste MTT) e genotoxicidade (teste dos micronúcleos, CBMN) com e sem mistura S9, em células V79 de Hamster chinês. O 3 $\beta$-(E)-cinamoileuforbol revelou-se fracamente citotóxico e sem atividade mutagênica ou genotóxica.
\end{abstract}

Euphorbia conspicua latex was fractionated into triterpenic and irritant fractions I and II. The triterpenic fraction afforded 15 known compounds and a new triterpene, $3 \beta-(E)$ cinnamoyleuphorbol. 20-O-Acetyl-3- $O$-angeloylingenol was isolated from irritant fraction II. The compounds euphol, $3 \beta$-acetoxyeupha-8,24-diene, $3 \beta$ - $(E)$-cinnamoyleuphorbol and 20-O-Acetyl3-O-angeloylingenol were evaluated for molluscicidal activity. 20-O-Acetyl-3- $O$-angeloylingenol presented $\mathrm{LC}_{100}$ value of $1 \mu \mathrm{g} \mathrm{mL} \mathrm{m}^{-1}$, equivalent to that of the standard molluscicide niclosamide. Compounds euphol, $3 \beta$-acetoxyeupha-8,24-diene and 3 $\beta$ - $(E)$-cinnamoyleuphorbol showed low molluscicidal activity. Mutagenic assays (Ames test with strains TA 98, 100 and 102) were performed with $3 \beta-(E)$-cinnamoyleuphorbol in the presence and absence of metabolic activation (S9 mix). In V79 cells, the cytotoxicity of $3 \beta-(E)$-cinnamoyleuphorbol was evaluated using the MTT assay and the genotoxicity was assessed using the cytokinesis-block micronucleus assay $(\mathrm{CBMN})$ with or without S9 mix. Mutagenic or genotoxic activity was not detected, and no significant cytotoxicity was observed for $3 \beta-(E)$-cinnamoyleuphorbol at lower doses.

Keywords: Euphorbia conspicua, molluscicidal activity, mutagenic activity, cytotoxic activity, genotoxicity, $3 \beta-(E)$-cinnamoyleuphorbol, 20-O-acetyl-3- $O$-angeloylingenol

\section{Introduction}

Euphorbia conspicua N. E. Br. ${ }^{1}$ (Euphorbiaceae) is a succulent tree endemic to Angola and is traditionally used as a treatment for dermatitis and leprosy wounds. ${ }^{2}$ The genus Euphorbia is the largest in the spurge family, with more than 1000 species divided into many subgenera and

*e-mail: disabel@ubi.pt sections. Many studies have investigated the use of several of these plants in folk medicine to treat cancerous conditions. ${ }^{3-5}$ Some Euphorbia species have been studied for molluscicidal properties against schistosomiasis or bilharzia, leading to the discovery of milliamines, the most potent molluscicides identified so far. ${ }^{6}$

Schistosomiasis is a major source of morbidity and mortality in developing countries. Three schistosome species infect humans: Schistosoma mansoni, S. haematobium and 
S. japonicum. Because freshwater snails are intermediate hosts for these parasites, ${ }^{7}$ the use of molluscicides is desirable in the integrated control of schistosomiasis. ${ }^{7}$ Currently, only niclosamide is widely used in control programs, and it is highly active at all stages of the snail life cycle and on schistosome larvae. Natural molluscicidal compounds isolated from a large number of plants have received much attention in hope that they might provide cheap, biodegradable and effective control agents in rural areas where schistosomiasis is endemic. ${ }^{8,9}$

As part of our ongoing study of the plants of Angola, ${ }^{2,10,11}$ we observed that Euphorbia conspicua latex exhibits strong molluscicidal activity ${ }^{2}$ and may be a potential source of bioactive compounds. This work intended to isolate and describe the constituents of the active fractions and to evaluate their effects. As a result, sixteen compounds were characterized, including a new natural product named $3 \beta-(E)$ cinnamoyleuphorbol (3). Compounds 1-3 and 16 were evaluated for their molluscicidal activity. The cytotoxicity, mutagenic and genotoxicity activities of compound $\mathbf{3}$ were evaluated using the MTT test, Ames test and cytokinesisblock micronucleus assay (CBMN), respectively.

\section{Results and Discussion}

Compounds euphol (1), ${ }^{12} 3 \beta$-acetoxyeupha-8,24-diene (2), ${ }^{13}$ cembrene-A (4), ${ }^{14}$ germacrene-B (5), ${ }^{15}$ $3 \beta$-acetoxyeuphorbol (6), ${ }^{16} 3 \beta$-acetoxycycloart-24-ene (7), ${ }^{17}$ $\beta$-amyrin (8), ${ }^{18,19} 3 \beta$ - $(E)$-cinnamoyl- $\beta$-amyrin $(\mathbf{9}),{ }^{19}$ $3 \beta-(E)$-cinnamoyloxyeupha-8,24-diene $(\mathbf{1 0}),{ }^{12}$ cycloart-

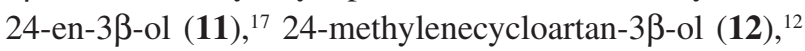
boeticol (13), ${ }^{20} 3 \beta$-acetoxylophenol (14), ${ }^{21}$ cholesterol $(\mathbf{1 5})^{22}$ and 20-O-acetyl-3- $O$-angeloylingenol (16) ${ }^{23}$ (Figure 1) were identified by comparison of experimental ${ }^{1} \mathrm{H}$ and ${ }^{13} \mathrm{C}$ NMR results with spectral data in the literature.

Compound 3 was obtained as a white amorphous solid, and its molecular formula $\mathrm{C}_{40} \mathrm{H}_{58} \mathrm{O}_{2}$ was established by HREIMS, showing a molecular ion peak $\mathrm{m} / \mathrm{z}$ of 570.4417 $\left[\mathrm{M}^{+}\right]$(calc. 570.4436) and 12 degrees of unsaturation. The IR spectrum revealed absorption bands for an ester (1720 and $1153 \mathrm{~cm}^{-1}$ ), a terminal methylene group $\left(890 \mathrm{~cm}^{-1}\right)$, a fully substituted double bond $\left(1640 \mathrm{~cm}^{-1}\right)$ and an aromatic ring $\left(1580,850,820\right.$ and $\left.679 \mathrm{~cm}^{-1}\right)$. The ${ }^{1} \mathrm{H}$ NMR spectrum (Table 1) exhibited a signal for a terminal methylene group $\left[\delta_{\mathrm{H}} 4.66\right.$ and $4.72(\mathrm{~s}, 1 \mathrm{H}$, each)], a secondary $(E)$-cinnamoyloxy group $\left[\delta_{\mathrm{H}} 6.44\right.$ and $7.67(\mathrm{~d}$, $1 \mathrm{H}, J 16.8 \mathrm{~Hz}$, each)] and eight methyl groups (five singlets $\left[\delta_{\mathrm{H}} 0.77,0.88,0.93,0.96\right.$ and $1.01,(3 \mathrm{H}$ each) $]$ as well as three doublets $\left[\delta_{\mathrm{H}} 1.02\right.$ and $1.03(3 \mathrm{H}, J 6.6 \mathrm{~Hz}$ each) and $0.94(3 \mathrm{H}, J 6.0 \mathrm{~Hz})])$. The methyl doublets $\delta_{\mathrm{H}} 1.02$ and $1.03(J 6.6 \mathrm{~Hz})$ and the methine septet $\delta_{\mathrm{H}} 2.23(J 6.6 \mathrm{~Hz})$ suggested the existence of an isopropyl group in the molecule; moreover, the multiplicity of the methine as a septet implied that the isopropyl group was bonded directly to a quaternary carbon. The ${ }^{13} \mathrm{C}$ NMR spectrum (Table 1 ) showed signals of two $\mathrm{sp}^{2}$ carbons of a tetrasubstituted double bond $\left(\delta_{\mathrm{C}} 133.6\right.$ and 134.0) along with signals of a terminal methylene group $\left(\delta_{\mathrm{C}} 156.9\right.$ and 106.0) and a cinnamate moiety $\left(\delta_{\mathrm{C}} 166.9,144.3\right.$ and 118.9).

Table 1. ${ }^{1} \mathrm{H} N M R$ and ${ }^{13} \mathrm{C}$ NMR data and $\mathrm{HMBC}$ correlations of compound 3 in $\mathrm{CDCl}_{3}{ }^{\mathrm{a}}$

\begin{tabular}{|c|c|c|c|}
\hline Position & $\delta_{\mathrm{C}}$ & $\delta_{\mathrm{H}}$ & HMBC \\
\hline 1 & 35.0 & $1.35 \mathrm{~m} \mathrm{H}-\alpha ; 1.78 \mathrm{~m} \mathrm{H}-\beta$ & $2,5,10,19$ \\
\hline 2 & 24.3 & $1.70 \mathrm{~m} \mathrm{H}-\alpha ; 1.62 \mathrm{~m} \mathrm{H}-\beta$ & $1,3,4,10$ \\
\hline 3 & 81.0 & $4.66 \mathrm{dd}(11.4,5.4) \mathrm{H}-\alpha$ & $2,4,28,29,1^{\prime}$ \\
\hline 4 & 38.1 & & \\
\hline 5 & 51.1 & 1.27 br d (12.0) H- $\alpha$ & $\begin{array}{c}1,3,4,6,7,9,10 \\
19,28,29\end{array}$ \\
\hline 6 & 18.7 & $1.71 \mathrm{~m} \mathrm{H}-\alpha ; 1.44 \mathrm{~m} \mathrm{H}-\beta$ & $4,5,7,8,10$ \\
\hline 7 & 27.5 & $1.95 \mathrm{~m} \mathrm{H}-\alpha ; 2.09 \mathrm{~m} \mathrm{H}-\beta$ & $5,8,9$ \\
\hline 8 & 133.6 & & \\
\hline 9 & 134.0 & & \\
\hline 10 & 37.2 & & \\
\hline 11 & 21.4 & $2.08 \mathrm{~m} \mathrm{H}-\alpha ; 1.94 \mathrm{~m} \mathrm{H}-\beta$ & $8,9,13$ \\
\hline 12 & 30.8 & $1.69 \mathrm{~m}$ & $9,11,13,17,18$ \\
\hline 13 & 44.1 & & \\
\hline 14 & 50.0 & & \\
\hline 15 & 29.8 & $1.55 \mathrm{~m} \mathrm{H}-\alpha ; 1.21 \mathrm{~m} \mathrm{H}-\beta$ & $13,16,17,30$ \\
\hline 16 & 28.0 & $1.35 \mathrm{~m} \mathrm{H}-\alpha ; 1.94 \mathrm{~m} \mathrm{H}-\beta$ & $13,20,22$ \\
\hline 17 & 50.0 & $1.51 \mathrm{~m} \mathrm{H}-\beta$ & $\begin{array}{c}13,14,16,18,20, \\
21\end{array}$ \\
\hline 18 & 15.4 & $0.77 \mathrm{~s} \mathrm{H}-\alpha$ & $12,13,14,17$ \\
\hline 19 & 20.2 & $1.01 \mathrm{~s} \mathrm{H}-\beta$ & $1,5,9,10$ \\
\hline 20 & 36.5 & $1.44 \mathrm{~m} \mathrm{H}-\alpha$ & 22,23 \\
\hline 21 & 18.8 & $0.94 \mathrm{~d}(6.0) \mathrm{H}-\beta$ & $17,20,22,23$ \\
\hline 22 & 35.1 & $1.15 \mathrm{~m} ; 1.56 \mathrm{~m}$ & $17,21,23$ \\
\hline 23 & 31.3 & $1.88 \mathrm{~m} ; 2.12 \mathrm{~m}$ & $22,24,25,24$ \\
\hline 24 & 156.9 & & \\
\hline 25 & 33.8 & $2.23 \mathrm{sept}(6.6)^{\mathrm{b}}$ & $23,24,26,27,24$ \\
\hline 26 & 22.0 & $1.02 \mathrm{~d}(6.6)$ & $24,25,27$ \\
\hline 27 & 21.8 & $1.03 \mathrm{~d}(6.6)$ & $24,25,26$ \\
\hline 28 & 28.0 & $0.93 \mathrm{~s} \mathrm{H}-\alpha$ & $3,4,5,29$ \\
\hline 29 & 16.8 & $0.96 \mathrm{~s} \mathrm{H}-\beta$ & $3,4,5,28$ \\
\hline 30 & 24.3 & $0.88 \mathrm{~s} \mathrm{H}-\beta$ & $8,13,14,15$ \\
\hline 24 & 106.0 & $4.66 \mathrm{~s} ; 4.72 \mathrm{~s}$ & 23,25 \\
\hline $1^{\prime}$ & 166.9 & & \\
\hline $2^{\prime}$ & 118.9 & $6.44 \mathrm{~d}(16.8)$ & $1^{\prime}, 1^{\prime \prime}$ \\
\hline 3 & 144.3 & $7.67 \mathrm{~d}(16.8)$ & 1', 1", 2", 6" \\
\hline $1 "$ & 134.6 & & \\
\hline 2", 6" & 128.0 & $7.52 \mathrm{~m}$ & 2", 3", 4", 5", 6" \\
\hline $3 ", 5 "$ & 128.8 & $7.37 \mathrm{~m}$ & 1", 2", 3", 5", 6" \\
\hline 4" & 130.1 & $7.37 \mathrm{~m}$ & 2", 3", 5", 6" \\
\hline
\end{tabular}

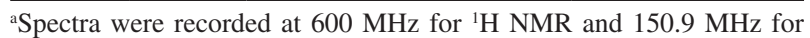
${ }^{13} \mathrm{C}$ NMR; 2D NMR experiments recorded in accordance; coupling constants $(J \mathrm{~Hz})$ are in parenthesis; ${ }^{\mathrm{b}}$ partially overlapped. 


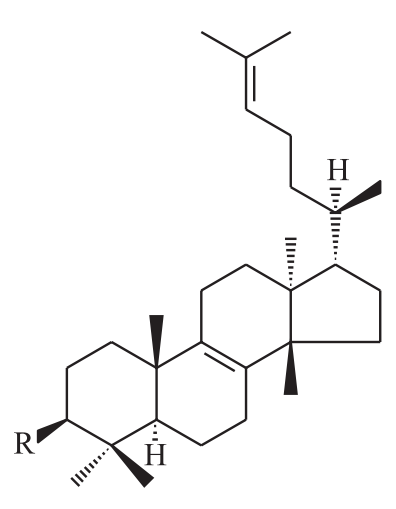

$1 \mathrm{R} \mathrm{OH}$

$2 \mathrm{R}$ AcO

10 R E-cynnamoyloxy
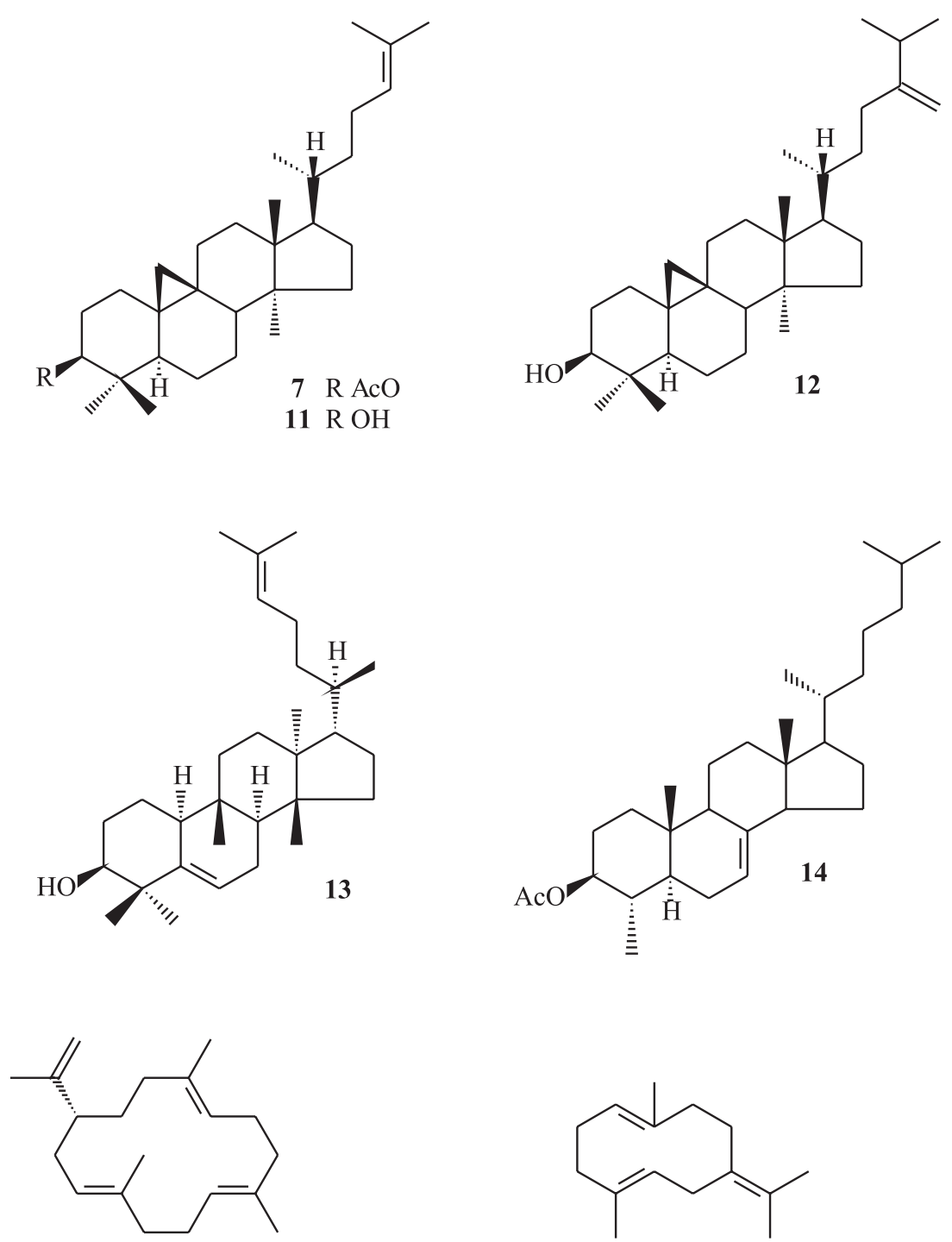

4

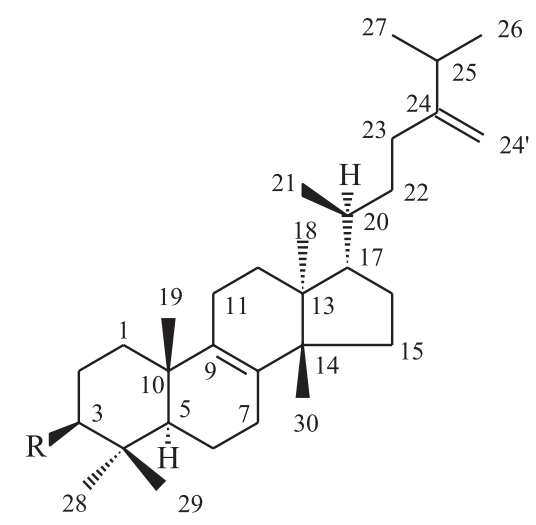

3 R E-cynnamoyloxy

$6 \mathrm{R} \mathrm{AcO}$<smiles>[R]C1CC[C@@]2(C)C(CC[C@]3(C)C2CC=C2C4CC(C)(C)CC[C@]4(C)CC[C@@]23C)C1(C)C</smiles>

$8 \mathrm{R} \mathrm{OH}$

$9 \mathrm{R}$ E-cynnamoyloxy

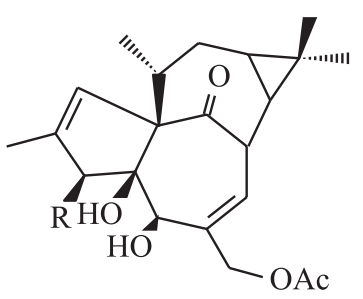

16 R Angeloyl A

16a R Dianthraniloyl peptide B<smiles>C/C=C(/C)C(=O)OC</smiles><smiles>COC(=O)c1ccccc1NC(=O)c1ccccc1</smiles>

Figure 1. Chemical structures of the isolated compounds. 
The EI mass spectrum revealed fragment ion peaks at $\mathrm{m} / \mathrm{z}$ $555\left([\mathrm{M}]^{+}-\mathrm{Me}\right), 407\left([\mathrm{M}]^{+}-\mathrm{Me}-\mathrm{HO}_{2} \mathrm{CCH}=\mathrm{CHC}_{6} \mathrm{H}_{5}\right), 297$ (loss of $\mathrm{C}_{9} \mathrm{H}_{17}$ and $\left.\mathrm{HO}_{2} \mathrm{CCH}=\mathrm{CHC}_{6} \mathrm{H}_{5}\right), 255\left(297-\mathrm{C}_{3} \mathrm{H}_{6}\right.$ ) and $241\left(255-\mathrm{CH}_{2}\right)$, which corroborated the structure as a $\Delta^{8-9}$ tetracyclic triterpene bearing a cinnamoyl group at the $\mathrm{C}-3$ position and a side chain containing nine carbon atoms, including isopropyl and C-24 methylene groups.
Analysis of ${ }^{1} \mathrm{H}$ and ${ }^{13} \mathrm{C}$ NMR spectra along with data from COSY (homonuclear correlation spectroscopy), HSQC (heteronuclear single-quantum correlation) and HMBC (heteronuclear multiple bond coherence) experiments (Table 1) suggested a euphane- or tirucallanetype triterpene. The NOESY (nuclear Overhauser enhancement spectroscopy) data (Figure 2) revealed ${ }^{1} \mathrm{H}-{ }^{1} \mathrm{H}$ long-range correlations between $\mathrm{Me}-29$ and Me-19,

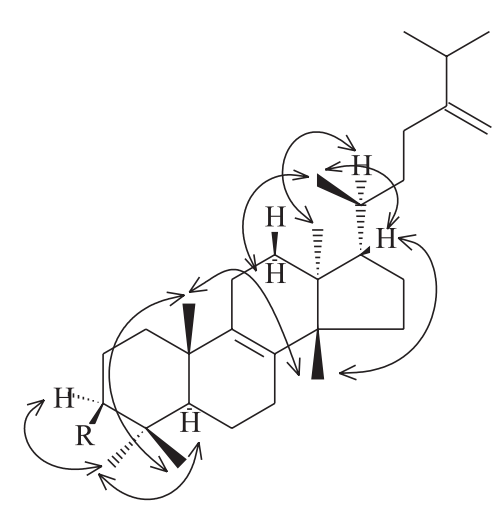

NOESY

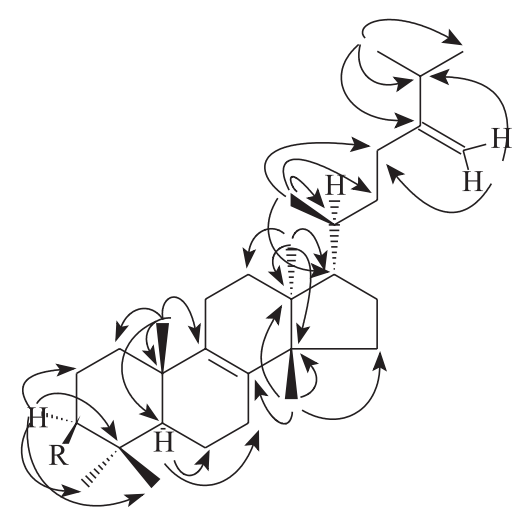

HMBC

Figure 2. Relenvat NOESY and HMBC correlations of 3.

Table 2. Molluscicidal activity of terpenes from Euphorbia conspicua N. E. Br. latex on Biomphalaria glabrata Say

\begin{tabular}{|c|c|c|c|c|c|}
\hline \multirow[t]{2}{*}{ Compound } & \multirow{2}{*}{$\begin{array}{l}\text { Snail diameter / } \\
\mathrm{mm}\end{array}$} & \multirow{2}{*}{$\begin{array}{l}\text { Concentration / } \\
\left(\mu \mathrm{g} \mathrm{mL} L^{-1}\right)\end{array}$} & \multicolumn{3}{|c|}{ Dead snails / \% } \\
\hline & & & After $24 \mathrm{~h}$ of exposure & After $24 \mathrm{~h}$ of recovering & After $48 \mathrm{~h}$ of recovering \\
\hline \multirow[t]{5}{*}{1} & $13-20$ & 100 & 0 & 20 & 20 \\
\hline & $13-20$ & 50 & 0 & 20 & 20 \\
\hline & $13-20$ & 20 & 0 & 0 & 0 \\
\hline & $15-21$ & 10 & 0 & 0 & 0 \\
\hline & $15-21$ & 1 & 0 & 0 & 0 \\
\hline \multirow[t]{5}{*}{2} & $15-20$ & 100 & 0 & 40 & 40 \\
\hline & $13-20$ & 50 & 0 & 40 & 40 \\
\hline & $13-20$ & 20 & 0 & 0 & 0 \\
\hline & $15-21$ & 10 & 0 & 0 & 0 \\
\hline & $15-21$ & 1 & 0 & 0 & 0 \\
\hline \multirow[t]{5}{*}{3} & $15-20$ & 100 & 0 & 20 & 20 \\
\hline & $13-20$ & 50 & 0 & 0 & 0 \\
\hline & $13-20$ & 20 & 0 & 0 & 0 \\
\hline & $15-21$ & 10 & 0 & 0 & 0 \\
\hline & $15-21$ & 1 & 0 & 0 & 0 \\
\hline \multirow[t]{6}{*}{16} & $15-17$ & 100 & 100 & - & - \\
\hline & $15-20$ & 10 & 0 & 100 & - \\
\hline & $15-20$ & 1 & 0 & 100 & - \\
\hline & $13-21$ & 0.1 & 0 & 60 & 60 \\
\hline & $13-21$ & 0.01 & 0 & 0 & 20 \\
\hline & $13-21$ & 0.001 & 0 & 0 & 20 \\
\hline Dechlorinated water & $15-20$ & & 0 & 0 & 0 \\
\hline $\begin{array}{l}\text { Dechlorinated water } \\
\text { with } 1 \% \text { DMSO }\end{array}$ & $15-21$ & & 0 & 0 & 0 \\
\hline Cupric sulfate & $15-20$ & 50 & 100 & - & - \\
\hline
\end{tabular}


Table 3. Effect of compound 3 on cell viability of V79 Chinese hamster cells using the MTT assay

\begin{tabular}{cc}
\hline Dose / $(\mu \mathrm{g}$ per well $)$ & Viability / \% ${ }^{\mathrm{a}}$ \\
\hline 25 & $115.4 \pm 5.1$ \\
50 & $123.0 \pm 8.1$ \\
250 & $59.7 \pm 37.1$ \\
\hline
\end{tabular}

aiability is expressed as percentage values relative to control cells; results are expressed as mean value $\%$ viability \pm standard deviations (SD) $(n=3)$; in each independent experiment four replicate cultures were used.

Me-30, H-17 and Me-21 on the $\beta$ face of the structure, $\mathrm{H}-3$ and $\mathrm{H}-5$ with Me-28, H-20 with Me-18 and H-12 $\alpha$ with Me-21. These data were consistent with a tirucallane-type structure. ${ }^{16,20,23}$ Thus, compound $\mathbf{3}$ was identified as a new natural product and named $3 \beta-(E)$-cinnamoyleuphorbol.

Compounds 1-3 and 16 were evaluated for molluscicidal activity against Biomphalaria glabrata, a vector of S. mansoni (Table 2). The molluscicidal activity of compound 16, with an $\mathrm{LC}_{100}$ of $1 \mu \mathrm{g} \mathrm{mL} \mathrm{m}^{-1}$, was equivalent to that of niclosamide, the synthetic compound used for the control of mollusks $\left(\mathrm{LC}_{100} 1.5 \mu \mathrm{g} \mathrm{mL}^{-1}\right){ }^{24}$ Compound $\mathbf{1 6}$ presented a dose dependent and continuous effect on adult snails after $24 \mathrm{~h}$ of exposure, while it was completely inactive against the egg masses. In contrast, the triterpenic compounds displayed weak activity. Compounds $\mathbf{1}$ and $\mathbf{3}$ caused 20\% mortality, while compound 2 cause $40 \%$ of mortality at a concentration of $100 \mu \mathrm{g} \mathrm{mL}^{-1}$. Due to a shortage of sample materials, the other triterpenic compounds were not tested.

The survival values in V79 cells are given in Table 3, highlighting that only a slight decrease of survival was observed for $250 \mu \mathrm{g}$ per well. Ames assay outcomes (Table 4) revealed compound 3 as a non-mutagenic agent on the strains tested at doses up to $250 \mu \mathrm{g}$ per plate. The results obtained for the induction of micronuclei in Chinese hamster cells (V79 cells) at concentrations up to $100 \mu \mathrm{g} \mathrm{mL} \mathrm{m}^{-1}$ revealed no significant increase compared to the negative control in the absence or presence of S9 mix (Table 5).

Table 4. Mutagenic activity of compound $\mathbf{3}$ in the Ames assay, revertants in three strains of Salmonella typhimurium (TA 98, TA100 and TA102) treated with different concentrations of compound $\mathbf{3}$ in the presence and absence of metabolic activation (S9)

\begin{tabular}{|c|c|c|c|c|c|c|}
\hline \multirow{3}{*}{$\begin{array}{l}\text { Dose / } \\
\text { ( } \mu \mathrm{g} \text { per plate) }\end{array}$} & \multicolumn{6}{|c|}{ Revertants per plate } \\
\hline & \multicolumn{2}{|c|}{ TA 98} & \multicolumn{2}{|c|}{ TA 100} & \multicolumn{2}{|c|}{ TA 102} \\
\hline & $-\mathrm{S} 9$ & $+\mathrm{S} 9$ & $-\mathrm{S} 9$ & $+\mathrm{S} 9$ & $-\mathrm{S} 9$ & $+\mathrm{S} 9$ \\
\hline 0 & $17.5 \pm 3.5$ & $27.5 \pm 9.2$ & $130.5 \pm 29.0$ & $123.5 \pm 20.5$ & $268.0 \pm 56.6$ & $342.0 \pm 31.1$ \\
\hline 5 & $15.0 \pm 1.4$ & $18.5 \pm 3.5$ & $127.5 \pm 33.2$ & $128.5 \pm 23.3$ & $259.5 \pm 36.1$ & $296.5 \pm 30.4$ \\
\hline 25 & $19.5 \pm 0.7$ & $18.0 \pm 7.1$ & $129.0 \pm 14.1$ & $124.0 \pm 14.1$ & $231.0 \pm 0$ & $309.5 \pm 51.6$ \\
\hline 50 & $16.5 \pm 0.7$ & $28.0 \pm 12.7$ & $116.5 \pm 14.8$ & $107.5 \pm 26.2$ & $288.5 \pm 55.9$ & $312.5 \pm 88.4$ \\
\hline 250 & $14.5 \pm 2.1$ & $20.5 \pm 13.4$ & $92.5 \pm 4.2$ & $87.5 \pm 13.4$ & $257.5 \pm 96.8$ & $260.5 \pm 132.2$ \\
\hline
\end{tabular}

Quercetin

$10 \quad 284.0 \pm 77.7 \quad 1314.5 \pm 102.5$

\section{$4-\mathrm{NQO}^{\mathrm{a}}$}

10

$1432 \quad 2842$

Values are presented as the mean \pm standard deviation $(\mathrm{SD})(\mathrm{n}=2)$; dose 0 as negative control; quercetin and 4-NQO as positive controls; 4 -NQO: 4-nitroquinoline-1-oxide.

Table 5. Effect of compound 3 on the frequency of micronucleated binucleated cells (\% MNBN) in V79 Chinese hamster cells in the presence (+S9) and absence (-S9) of metabolic activation

\begin{tabular}{|c|c|c|c|c|}
\hline \multirow[t]{2}{*}{ Test compound } & \multicolumn{2}{|c|}{$\% \mathrm{MNBN}$} & \multicolumn{2}{|c|}{$\% \mathrm{BN}$} \\
\hline & $-\mathrm{S} 9$ & $+\mathrm{S} 9$ & $-\mathrm{S} 9$ & $+\mathrm{S} 9$ \\
\hline \multicolumn{5}{|c|}{ Compound $3 /\left(\mu \mathrm{g} \mathrm{mL}^{-1}\right)$} \\
\hline 0 & $0.3 \pm 0.1$ & $0.2 \pm 0.2$ & $41.0 \pm 14.2$ & $37.4 \pm 2.3$ \\
\hline 20 & $0.4 \pm 0.2$ & $0.2 \pm 0.0$ & $32.5 \pm 5.1$ & $36.1 \pm 1.0$ \\
\hline 100 & $0.3 \pm 0.0$ & $0.1 \pm 0.1$ & $44.2 \pm 1.6$ & $35.2 \pm 1.8$ \\
\hline \multicolumn{5}{|l|}{ Mytomicin C } \\
\hline $2.5 \mu \mathrm{g} \mathrm{mL}^{-1}$ & $10.5 \pm 1.8$ & - & $25.0 \pm 4.2$ & - \\
\hline \multicolumn{5}{|c|}{ Cyclophosphamide } \\
\hline $2.0 \mu \mathrm{g} \mathrm{mL}^{-1}$ & - & $2.1 \pm 0.3$ & - & $38.6 \pm 0.1$ \\
\hline
\end{tabular}




\section{Conclusions}

E. conspicua, a succulent tree endemic to Angola, was previously evaluated for its molluscicidal activity, ${ }^{2}$ but the latex chemical composition was not determined. The present study revealed that E. conspicua latex is composed mainly of triterpenes with euphane and cycloartane skeletons along with other triterpenes and ingenane diterpenes and contains a new compound with a tirucallane skeleton, $3 \beta-(E)$-cinnamoyleuphorbol (3). Four of the isolated compounds, 1-3 and 16, were evaluated for their molluscicidal activity. Compound $\mathbf{1 6}$ was found to be the most active, with an $\mathrm{LC}_{100}$ value of $1 \mu \mathrm{g} \mathrm{mL} \mathrm{m}^{-1}$, which is similar to that for milliamine $\mathrm{L}$, the most powerful molluscicide of plant origin characterized thus far. ${ }^{25}$ Although compound $\mathbf{1 6}$ and milliamine $\mathrm{L}$ are structurally differing from each other at the position C-3, where milliamine $\mathrm{L}$ bears a dianthraniloyl peptide group and compound $\mathbf{1 6}$ an angeloyl group, molluscidal activity remains. At this point compound $\mathbf{1 6}$ seems to be the major responsible for E. conspicua molluscicidal activity but further investigation is needed. Compound $\mathbf{1 6}$ was found to be totally inactive against the egg masses of $B$. glabrata. Compound $\mathbf{3}$ was evaluated for its cytotoxicity, mutagenic activity and genotoxicity using the MTT test, the Ames test and the cytokinesis-block micronucleus assay (CBMN), respectively. No mutagenic or genotoxic activity was detected and little or no cytotoxicity was found concluding that this particular compound as no potential risk regarding their future use as bioactive compound.

The irritant properties of the latex can explain the etnopharmacological use against leprosy wounds and dermatitis in general, but more studies are needed to validate this idea.

Biological and chemical evaluation of other components of E. conspicua latex will require large amounts of latex and will be the subject of a future study.

\section{Experimental}

\section{General experimental procedures}

Optical rotations were obtained with a Bellingham+Stanley Ltd ADP 220 polarimeter. HREIMS measurements were conducted on a VG Autospec M and recorded at $70 \mathrm{eV}$. The mass spectrum of $\mathbf{3}$ was obtained from a GC-MS (Hewlett-Packard 5989 A) spectrometer. The IR spectra were recorded in a Unicam Mattson 5000 FTIR. NMR spectra of $\mathbf{3}$ were recorded in a Bruker Avance II $600 \mathrm{MHz}\left({ }^{1} \mathrm{HNMR}\right)$ and $150.9 \mathrm{MHz}\left({ }^{13} \mathrm{CNMR}\right)$ spectrometer in $\mathrm{CDCl}_{3}$. Spectra of compounds 1-2 and 4-16 were recorded in a Bruker AC 250P $250 \mathrm{MHz}\left({ }^{1} \mathrm{H}\right.$ NMR) and $62.9 \mathrm{MHz}\left({ }^{13} \mathrm{C} \mathrm{NMR}\right)$ spectrometer in $\mathrm{CDCl}_{3}$. Chemical shifts are given in $\delta \mathrm{ppm}$ and are referenced to residual $\mathrm{CHCl}_{3}, 7.26 \mathrm{ppm}$ for the ${ }^{1} \mathrm{H}$ and $77.0 \mathrm{ppm}$ for ${ }^{13} \mathrm{C}$. Two-dimensional experiments were performed with standard Bruker software. Column chromatography was conducted on silica gel 60 (70-230 mesh, Merck, Darmstadt, Germany).

\section{Plant material}

Plant material was collected at Cacuaco, Luanda and was identified by Professor Esperança da Costa from Agostinho Neto University (Biology Department). A voucher specimen (No 4498) has been deposited at the Luanda Herbarium, Luanda, Angola.

\section{Extraction and isolation}

The latex $(900 \mathrm{~g})$ was collected and frozen $\left(-20^{\circ} \mathrm{C}\right)$. Defrosted latex was dissolved in $\mathrm{MeOH}$ at $50{ }^{\circ} \mathrm{C}$, and then maintained at room temperature $\left(22-23{ }^{\circ} \mathrm{C}\right)$ until a solid formed; the solid material was separated by filtration and exhaustively extracted with $\mathrm{Me}_{2} \mathrm{CO}$ at $40{ }^{\circ} \mathrm{C} .{ }^{2}$ The $\mathrm{Me}_{2} \mathrm{CO}$ fraction was evaporated and redissolved in $\mathrm{MeOH} / \mathrm{H}_{2} \mathrm{O}(1: 1)$ and subsequently extracted with hexane. The hexane fraction $(30 \mathrm{~g})$ was analyzed by ${ }^{1} \mathrm{H}$ and ${ }^{13} \mathrm{C}$ NMR and identified as the triterpenic fraction. ${ }^{17}$ The metanolic filtrate, obtained from the defrosted latex, was evaporated to dryness and extracted with hexane to yield fraction I $(1 \mathrm{~g})$; the insoluble portion was dissolved in $\mathrm{MeOH}-\mathrm{H}_{2} \mathrm{O}(1: 1)$ and extracted with $\mathrm{Et}_{2} \mathrm{O}$ (fraction II, $2 \mathrm{~g}$ ). ${ }^{26}$ Due to their irritant proprieties to the eyes and skin of the operator, fractions I and II were named irritant fractions. ${ }^{26}$ The triterpenic fraction $(30 \mathrm{~g})$ was submitted to column chromatography (CC) over silica gel 60 (Merck) using a gradient elution from 100\% hexane, hexane/toluene $(9: 1,8: 2,7: 3,1: 1)$, toluene/EtOAc (95:5, 9:1, 7:3) to $100 \%$ EtOAc. A total of 140 fractions of $c a .100 \mathrm{~mL}$ each were collected and pooled into ten fractions. Fraction 1 afforded cembrene-A (4) $(6 \mathrm{mg})$. Fraction 2 yielded germacrene-B (5) (10 mg). Column chromatography of fraction 5 on $10 \% \mathrm{AgNO}_{3} /$ silica gel 60 (Merck) $(\mathrm{m} / \mathrm{m})$ using a hexane/EtOAc gradient elution, from $100 \%$ hexane to $100 \%$ EtOAc, afforded $3 \beta$-acetoxyeupha8,24-diene (2) (35 mg), 33-acetoxyeuphorbol (6) (5 mg), $3 \beta$-acetoxycycloart-24-ene (7) $(12 \mathrm{mg})$ and $\beta$-amyrin (8) $(11 \mathrm{mg})$. Column chromatography of fraction 6 on silica gel 60 (Merck) using hexane, hexane/toluene (95:5, 9:1, 8:2, 7:3, 1:1) and toluene/EtOAc (99:1, 95:5, 9:1, 8:2, 7:3, 6:4, 1:1) yielded euphol (1) $(65 \mathrm{mg}), 3 \beta$ - $(E)$-cinnamoyleuphorbol (3) $(60 \mathrm{mg}), 3 \beta-(E)$-cinnamoyl- $\beta$-amyrin (9) (18 $\mathrm{mg})$ and $3 \beta-(E)$-cinnamoyloxyeupha-8,24-diene (10) 
(15 mg). Column chromatography of fraction 7 on $10 \%$ $\mathrm{AgNO}_{3} /$ silica gel 60 (Merck) $(\mathrm{m} / \mathrm{m})$ using hexane/EtOAc (95:5, 9:1, 8:2, 7:3, 6:4, 1:1) afforded cycloart-24-en-3ß-ol (11) $(11 \mathrm{mg})$ and 24-methylenecycloartan-3 $\beta$-ol (12) $(14 \mathrm{mg})$. Column chromatography of fraction 8 on silica gel 60 (Merck) using a hexane/EtOAc gradient yielded boeticol (13) (7 mg), 33-acetoxylofenol (14) (10 mg) and cholesterol (15) $(33 \mathrm{mg})$. Irritant fraction II $(2 \mathrm{~g})$ was submitted to column chromatography (CC) over silica gel 60 (Merck) using a gradient elution from $100 \%$ hexane to hexane/EtOAc (95:5, 9:1, 8:2 7:3, 1:1). A total of 76 fractions of $c a .50 \mathrm{~mL}$ each were collected and pooled into six fractions. Column chromatography of fraction 5 on $10 \% \mathrm{AgNO}_{3}$ /silica gel 60 (Merck) $(\mathrm{m} / \mathrm{m})$ with hexane/diethyl ether (95:5, 9:1, 8:2, 7:3) yielded 20-O-acetyl-3- $O$-angeloylingenol (16) $(22 \mathrm{mg}$ ).

\section{3ß-(E)-Cinnamoyleuphorbol (3)}

White amorphous solid; $[\alpha]_{\mathrm{D}}^{20}-19.0^{\circ}\left(c 1.33, \mathrm{CHCl}_{3}\right)$; IR (KBr) $v_{\max } / \mathrm{cm}^{-1}: 3040,3015,3021,1720,1640,1580$, $1153,890,850,820,679 ;{ }^{1} \mathrm{H}$ NMR $\left(\mathrm{CDCl}_{3}, 600 \mathrm{MHz}\right)$ and ${ }^{13} \mathrm{C}$ NMR $\left(\mathrm{CDCl}_{3}, 150.9 \mathrm{MHz}\right)$ : see Table 1 ; HREIMS $\mathrm{m} / \mathrm{z}$ $570.4417[\mathrm{M}]^{+}$(calcd for $\mathrm{C}_{40} \mathrm{H}_{58} \mathrm{O}_{2}, 570.4436$ ).

\section{Molluscicide activity}

The snail colony (B. glabrata) was sustained as described. ${ }^{27,28}$ Molluscicidal activity for adults and egg masses of $B$. glabrata was evaluated according to established procedures..$^{27-30}$

\section{MTT reduction assay.}

MTT assay is a cell viability assay based on conversion of MTT dye by mitochondrial enzymes of viable cells into a formazan which can be spectrophotometrically measured. In this assay the absorbance is proportional to the number of viable cells. ${ }^{31}$

The MTT assay was conducted on V79 Chinese hamster cells. Approximately $10^{4}$ cells were grown at $37{ }^{\circ} \mathrm{C}$ in a $5 \% \mathrm{CO}_{2}$ atmosphere for $24 \mathrm{~h}$ in 96 -well plates in $200 \mu \mathrm{L}$ of Ham's F-10 medium supplemented with $10 \%$ newborn calf serum and $1 \%$ penicillin/streptomycin solution. Different doses of the compound (25, 50 and $250 \mu \mathrm{g}$ per well) were added, and the cells were incubated for $3 \mathrm{~h}$. The medium was removed, and cells were incubated for $3 \mathrm{~h}$ with MTT $\left(0.5 \mathrm{mg} \mathrm{mL}^{-1}\right)$. The cells were washed carefully with PBS, and then $200 \mu \mathrm{L}$ of DMSO was added to each well. The absorbance of the converted dye was measured at $595 \mathrm{~nm}$ in a Zenith 3100 microplate reader. Cell viability was assessed by comparing the absorbance values of treated cells with that of the control. Absorbance values presented by V79 cell cultures without the addition of compound $\mathbf{3}$, i.e. control cultures, correspond to $100 \%$ of cell viability. Three independent experiments were performed. In each independent experiment four replicate cultures were used.

\section{Ames assay}

Mutagenicity testing was conducted by the plate incorporation assay described by Maron and $\mathrm{Ames}^{32}$ using Salmonella typhimurium strains TA 98, TA 100 and TA 102 in the presence or absence of S9 mix. ${ }^{32}$ At least two independent experiments were performed for each assay. Quercetin and 4-nitroquinoline-1-oxide were used as positive controls and dose 0 as negative control.

\section{Cytokinesis-block micronucleus assay (CBMN)}

Approximately $5 \times 10^{5} \mathrm{~V} 79$ Chinese hamster cells were cultured for $24 \mathrm{~h}$ in $25 \mathrm{~cm}^{2}$ culture flasks and then exposed to compound 3 at concentrations of 20 and $100 \mu \mathrm{g} \mathrm{mL}^{-1}$. Mitomycin C $\left(2.5 \mu \mathrm{g} \mathrm{mL}^{-1}\right)$ or cyclophosphamide $\left(2.0 \mu \mathrm{g} \mathrm{mL}^{-1}\right)$ was used as a positive control with and without $\mathrm{S} 9$ mix and dose 0 as negative control, respectively. $24 \mathrm{~h}$ after the genotoxic treatment, the cells were washed with fresh culture medium, and cytochalasin-B (Cyt-B) was added to a final concentration of $4.5 \mu \mathrm{g} \mathrm{mL}^{-1}$. The cells were incubated for additional $16 \mathrm{~h}$, harvested by trypsinization, rinsed and submitted to a mild hypotonic treatment as described elsewhere. ${ }^{33}$ The centrifuged cells were placed onto dry slides, and smears were made. After air-drying, the slides were fixed with cold methanol for $30 \mathrm{~min}$. One day later, the slides were stained with Giemsa (4\% (v/v) in $0.01 \mathrm{~mol} \mathrm{~L}^{-1}$ sodium phosphate buffer, $\mathrm{pH} 6.8$ ) for $10 \mathrm{~min}$. For each experimental point, 1000 binucleate V79 cells (BN) with well-preserved cytoplasm were scored. Micronuclei were identified under a light microscope using a magnification of $1250 \times$ according to the criteria proposed by Caria et al. $^{34} \mathrm{We}$ evaluated MN/BN (data not showed), which represents the average number of micronuclei per binucleated cell, and the frequency of micronucleated binucleated V79 cells (\% MNBN), which represents the fraction of cytokinesis blocked (binucleated) cells with micronuclei, regardless of the number of micronuclei per BN cell. ${ }^{35}$ At least two independent experiments were performed for each assay.

\section{Cell proliferation}

The decrease in cell proliferation in the experiments described above was assessed by determining the frequency 
of binucleate cells (\% BN). ${ }^{35}$ For this index 1000 cells with well-preserved cytoplasm were analyzed according to number of nuclei at a magnification of $500 \times$. Two independent experiments were conducted.

\section{Supplementary Information}

${ }^{1} \mathrm{H}$ NMR, ${ }^{13} \mathrm{C}$ NMR, ${ }^{1} \mathrm{H}-{ }^{1} \mathrm{H}$ COSY, HSQC, HMBC and NOESY NMR spectra of compound $\mathbf{3}$ and physical data of compounds 1, 2 and $\mathbf{1 6}$ are available free of charge at http://jbcs.org.br as a PDF file.

\section{Acknowledgements}

This work was supported by Conselho Nacional de Desenvolvimento Científico e Tecnológico (CNPq) and Coordenação de Aperfeiçoamento de Pessoal de Nível Superior (CAPES) through scholarships and financial support. This work was partially funded by projects POCTI/QUI/39380/2001 and FCOMP-01-0124FEDER-007430 (under COMPETE with FEDER funding) of Fundação para a Ciência e Tecnologia (FCT) and the Textile and Paper Materials Center. Rosalina Mata is thankful to AULP and INABE for financial support.

\section{References}

1. Brown, N. E.; In Fl. Trop. Afr. 1912, 6, 600.

2. dos Santos, A. F.; Lopes, L. A.; Mata, R. C. S.; de Mendonça, D. I. M. D.; Sant'Ana, A. E. G.; Bioresour. Technol. 2007, 98, 135.

3. Uemura, B.; Katayama, C.; Luno, E.; Sasaki, K.; Hirata, Y.; Tetrahedron Lett. 1975, 1703.

4. Appendino, G.; Jakupovic, S.; Tron, C. G.; Jakupovic, J.; Milon, V.; Ballero, M.; J. Nat. Prod. 1998, 61, 749.

5. Alberto, J. M.; Sanz-Cervera, J. F.; Alberto, Y.; Jakupovic, J.; J. Nat. Prod. 1999, 62, 110.

6. Hecker, E.; Pure Appl. Chem. 1977, 49, 1423.

7. http://www.who.int/topics/schistosomiasis/en/accessed in June 2011.

8. Hostettman, K.; Marston, A; Ndjoko, K.; Wolfender, J. L.; Curr. Org. Chem. 2000, 4, 973.

9. Queiroz, E. F.; Ahua, K. M.; Hostettman, K.; Chimia 2005, 59, 299.

10. Borges, C. M. P.; Diakanawma, C.; de Mendonça, D. I. M. D.; J. Braz. Chem. Soc. 2010, 21, 1121.

11. Sebastião, N'S. N.; Cordeiro, I. J. S.; dos Santos, A. F.; Gaspar, J. F.; Martins, C.; Rueff, J.; Diakanamwa, C.; Sant'Ana, A. E. G.; de Mendonça, D. I. M. D.; Phytochemistry 2010, 71, 798.

12. Gewali, M. B.; Hattori, M.; Tezuka, Y.; Kikuchi, T.; Namba, T.; Phytochemistry 1990, 29, 1625.
13. Akihisa, T.; Kimura, Y.; Koike, K.; Shibata, T.; Yoshida, Z.; Nikaido, T.; Tamura, T.; J. Nat. Prod. 1998, 61, 409.

14. Bai, B.; Jai, M.; Magn. Reson. Chem. 2008, 46, 791.

15. Brown, E. D.; Sam, T. W.; Sutherland, J. K.; Torre, A.; J. Chem. Soc., Perkin Trans. 1 1975, 2326; Adio, A. M.; PhD Thesis, Institute of Organic Chemistry, University of Hamburg, Germany, 2005; http://deposit.ddb. de/cgi-bin/dokserv?idn=974207071\&dok_var=d1\&dok_ ext=pdf\&filename=974207071.pdf accessed in June 2011.

16. Akihisa, T.; Wijeratne, E. M. K.; Tokuda, H.; Enjo, F.; Toriumi, M.; Kimura, Y.; Koike, K.; Nikaido, T.; Tezuka, Y.; Nishino, H.; J. Nat. Prod. 2002, 65, 158.

17. Teresa, J. P.; Urones J. G.; Marcos, I. S.; Basabe, P.; Cuadrado, M. J. S.; Moro, R. F.; Phytochemistry 1987, 26, 1767.

18. Chen, H.; Jia, Z-J.; Indian J. Chem. B. 1996, 35B, 1308.

19. Atta-Ur-Rahman; Pentacyclic Triterpenoids, vol. 2; Elsevier Science B.V.: Amsterdam, 1994, pp. 21, 443.

20. Ferreira, M. J. U.; Ascenso, J. R.; Tavares, O. S.; J. Nat. Prod 1995, 58, 275.

21. Bonerji, R.; Misra, G.; Nigam, S. K.; Phytochemistry 1987, 26, 2644.

22. Kovganko, N. V.; Kashkan, Zh. N.; Borisov, E. V.; Chem. Nat. Compd. 2000, 36, 595.

23. Akihisa, T.; Kimura, Y.; Kokke, W. C. M. C.; Takase, S.; Yasukama, K.; Tamura, T.; J. Chem. Soc., Perkin Trans. 1 1996, 1, 2379.

24. Perret, S.; Whitfield, P. J.; Parasitol. Today 1996, 12, 156.

25. Zani, C. L.; Marston, A.; Hamburger, M.; Hostettmann, K.; Phytochemistry 1993, 34, 89.

26. Urones, J. G.; Barcala, P. B.; Cuadrado, M. J. S.; Marcos, I. S.; Phytochemistry 1988, 27, 207.

27. Santos, A. F.; Sant'Ana, A. E. G.; Phytother. Res. 1999, 13, 660.

28. Santos, A. F.; Sant'Ana, A. E. G.; Phytomedicine 2000, 6, 431.

29. Thiilborg, S. T.; Christensen, S. B.; Cornet, C.; Olsen, C. E.; Lemmich, E.; Phytochemistry 1994, 36, 753.

30. World Health Organization (WHO); Bull. WHO 1965, 33, 567.

31. Carmichael, J.; DeGraff, W. G.; Gazdar, A. F.; Minna, J. D.; Mitchell, J. B.; Cancer Res. 1987, 47, 936.

32. Maron, D. M.; Ames, B. N.; Mutat. Res. 1983, 113, 173.

33. Van Hummelen, P.; Kirsch-Volders, M.; Mutagenesis 1990, 5 , 203.

34. Caria, H.; Chaveca, T.; Laires, A.; Rueff, J.; Mutat. Res. 1995 , 343,85

35. Oliveira, N. G.; Castro, M.; Rodrigues, A. S.; Gonçalves, I. C.; Cassapo, R.; Fernandes, A. P.; Chaveca, T.; Toscano-Rico, J. M.; Rueff, J.; Mutagenesis 2001, 16, 369.

Submitted: March 10, 2011 Published online: July 21, 2011 
Molluscicidal Activity of Compounds Isolated from Euphorbia conspicua N. E. Br.

\author{
Rosalina C. S. Mata, ${ }^{a}$ Dina I. M. D. de Mendonça, ${ }^{*, b}$ Liliana Vieira ${ }^{b}$ \\ Aldenir F. dos Santos, ${ }^{c}$ Luciana A. da Silva, ${ }^{c}$ Jorge F. Gaspar, ${ }^{d}$ Célia Martins, ${ }^{d}$ \\ José Rueff, ${ }^{d}$ and Antônio E. G. Sant'Ana ${ }^{c}$ \\ ${ }^{a}$ Chemistry Department, Agostinho Neto University, Luanda, Angola \\ ${ }^{b}$ Textile and Paper Materials Center, University of Beira Interior, 6200-001 Covilhã, Portugal \\ ${ }^{c}$ Chemistry Department, Federal University of Alagoas, 57092-970 Maceió-AL, Brazil \\ ${ }^{d}$ Department of Genetics, Faculty of Medical Sciences, New University of Lisbon, Lisbon, Portugal
}

Physical data of compounds 1, 2 and 16

Euphol (1)

White amorphous solid; $[\alpha]_{\mathrm{D}}^{20}+35.0^{\circ}\left(c 0.70, \mathrm{CHCl}_{3}\right)$; IR $(\mathrm{KBr}) v_{\max } / \mathrm{cm}^{-1}: 3580,3089,2980,1640,1450,1375$, 1151, 1131; ${ }^{1} \mathrm{H}$ NMR $\left(\mathrm{CDCl}_{3}, 250 \mathrm{MHz}\right) \delta 5.08(\mathrm{t}, 1 \mathrm{H}$, $J 7.0 \mathrm{~Hz}, \mathrm{H}-24), 3.23$ (dd, 1H, J 12.1 and $4.8 \mathrm{~Hz}, \mathrm{H}-3$ ), 1.68 (s, 3H, Me-27), 1.60 (s, 3H, Me-26), 0.99 (s, 3H, Me-19), 0.98 (s, 3H, Me-29), 0.87 (s, 3H, Me-28), 0.85 (d, 3H, $J 6.6 \mathrm{~Hz}, \mathrm{Me}-21$ ), 0.79 (s, 3H, Me-30), 0.75 (s, 3H, Me-18).

3 $\beta$-Acetoxyeupha-8,24-diene (2)

White amorphous solid; $[\alpha]_{\mathrm{D}}^{20}+38.3^{\circ}\left(c 0.28, \mathrm{CHCl}_{3}\right)$; IR (KBr) $v_{\max } / \mathrm{cm}^{-1}: 3060,1735,1640,1385,1380,1250$; ${ }^{1} \mathrm{H} \mathrm{NMR}\left(\mathrm{CDCl}_{3}, 250 \mathrm{MHz}\right) \delta 5.09($ br t, $1 \mathrm{H}, J 6.9 \mathrm{~Hz}$, H-24), 4.50 (dd, 1H, J 11.1 and 4.9 Hz, H-3), 2.04 (s, $\left.3 \mathrm{H},-\mathrm{OOCCH}{ }_{3}\right) 1.68$ (s, 3H, Me-27), 1.60 (s, 3H, Me-26) 0.98 (s, 3H, Me-19), 0.97 (s, 3H, Me-29), 0.88 (d, 3H, J $7.5 \mathrm{~Hz}, \mathrm{Me}-21$ ), 0.87 (s, 6H, Me-28 and Me-30), 0.74 (s, 3H, Me-18).

20-O-Acetyl-3-O-angeloylingenol (16)

Oil; IR (film) $v_{\max } / \mathrm{cm}^{-1}: 3460,3051,1725,1705,1695$ 1665, 1245, 1160; ${ }^{1} \mathrm{H} \mathrm{NMR}\left(\mathrm{CDCl}_{3}, 250 \mathrm{MHz}\right) \delta 6.16$ (m, 1H, H-3'), 6.12 (d, 1H, J $4.1 \mathrm{~Hz}, \mathrm{H}-7), 6.04$ (d, 1H, $J 1.6 \mathrm{~Hz}, \mathrm{H}-1), 5.56$ (s, 1H, H-3), 4.76 and 4.48 (d, 1H each, $J 12.7 \mathrm{~Hz}, \mathrm{H}-20), 4.09$ (dd, 1H, J 10.6 and $4.9 \mathrm{~Hz}$, H-8), 3.90 (br s, 1H, H-5), 3.46 (s, 1H, OH), 2.50 (m, 1H, H-11), 2.01 (m, 3H, Me-4'), 1.92 (br s, 3H, Me-2'), 1.80 (br s, 3H, Me-19), 1.05 (s, 3H, Me-16), 1.08 (s, 3H, Me17), 0.97 (d, 3H, J 7.1 Hz, Me-18), 0.96 (m, 1H, H-14), 0.68 (t, 1H, J 8.0, H-13). 

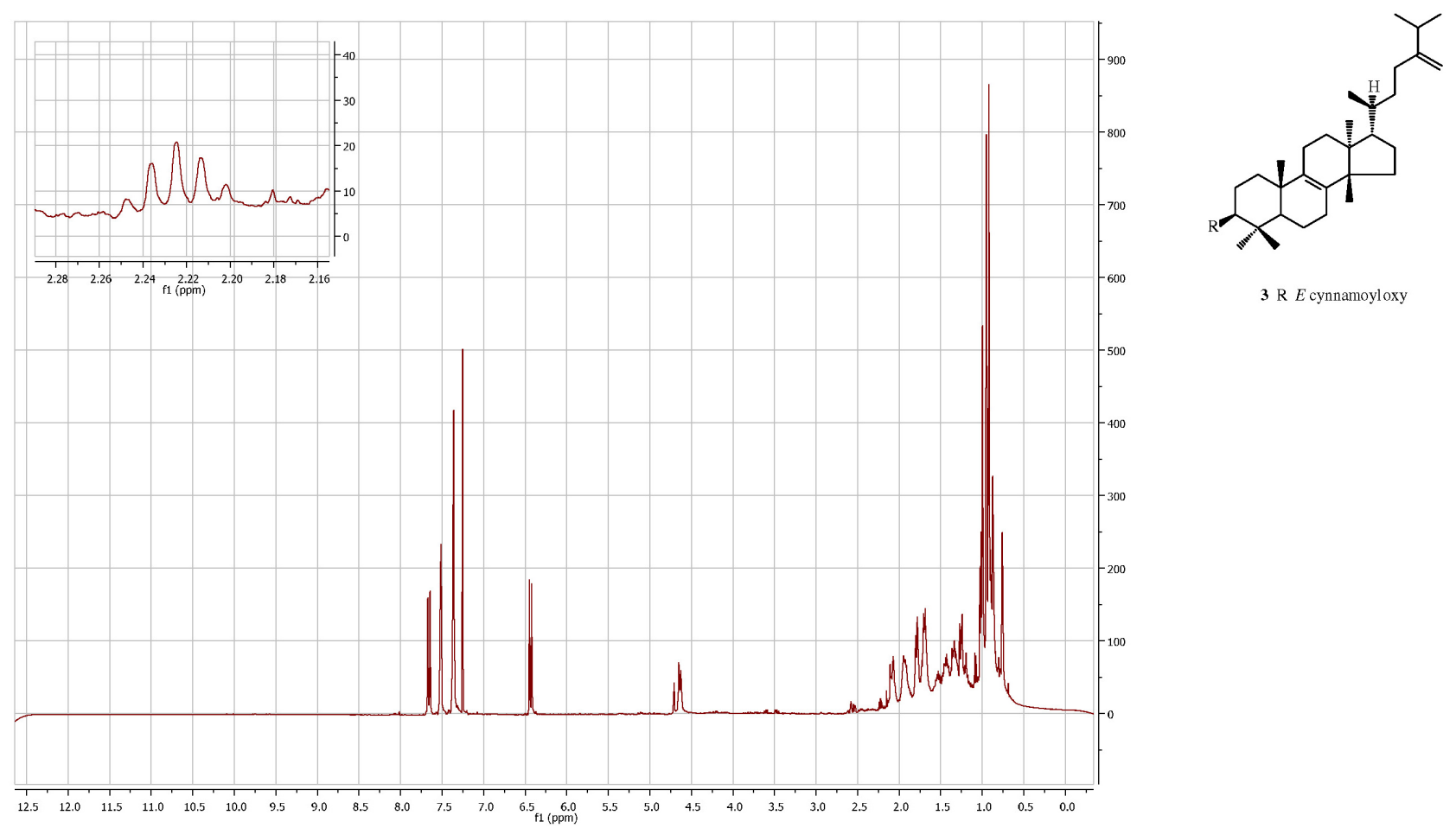

3 R E cynnamoyloxy

Figure S1. ${ }^{1} \mathrm{H}$ NMR spectrum $\left(600 \mathrm{MHz}, \mathrm{CDCl}_{3}\right)$ of compound 3 .
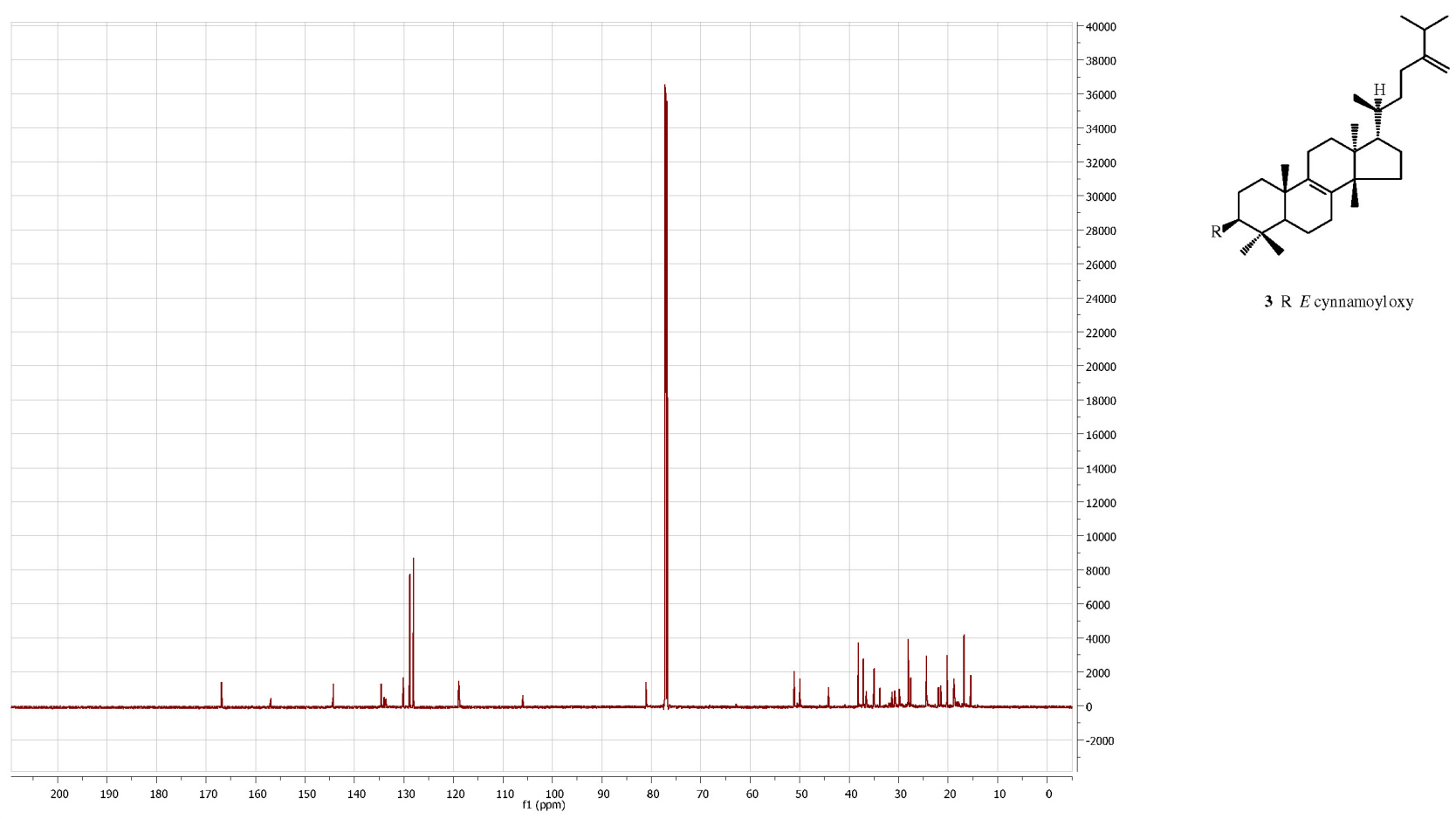

3 R E cynnamoyloxy

Figure S2. ${ }^{13} \mathrm{C}$ NMR spectrum $\left(150.9 \mathrm{MHz}, \mathrm{CDCl}_{3}\right)$ of compound 3 . 

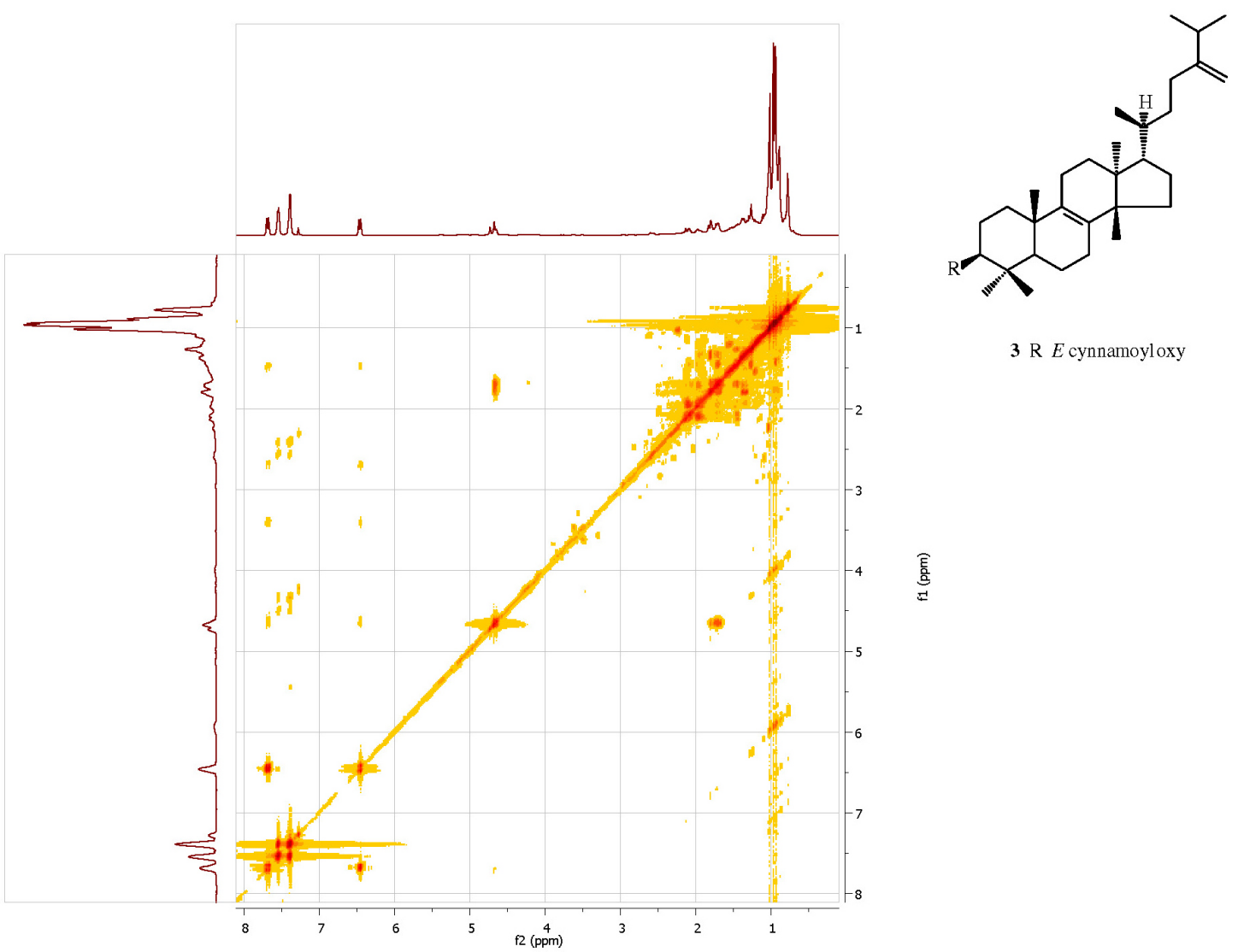

3 R E cynnamoyloxy

Figure S3. ${ }^{1} \mathrm{H}-{ }^{1} \mathrm{H}$ COSY spectrum $\left(600 \mathrm{MHz}, \mathrm{CDCl}_{3}\right)$ of compound 3.
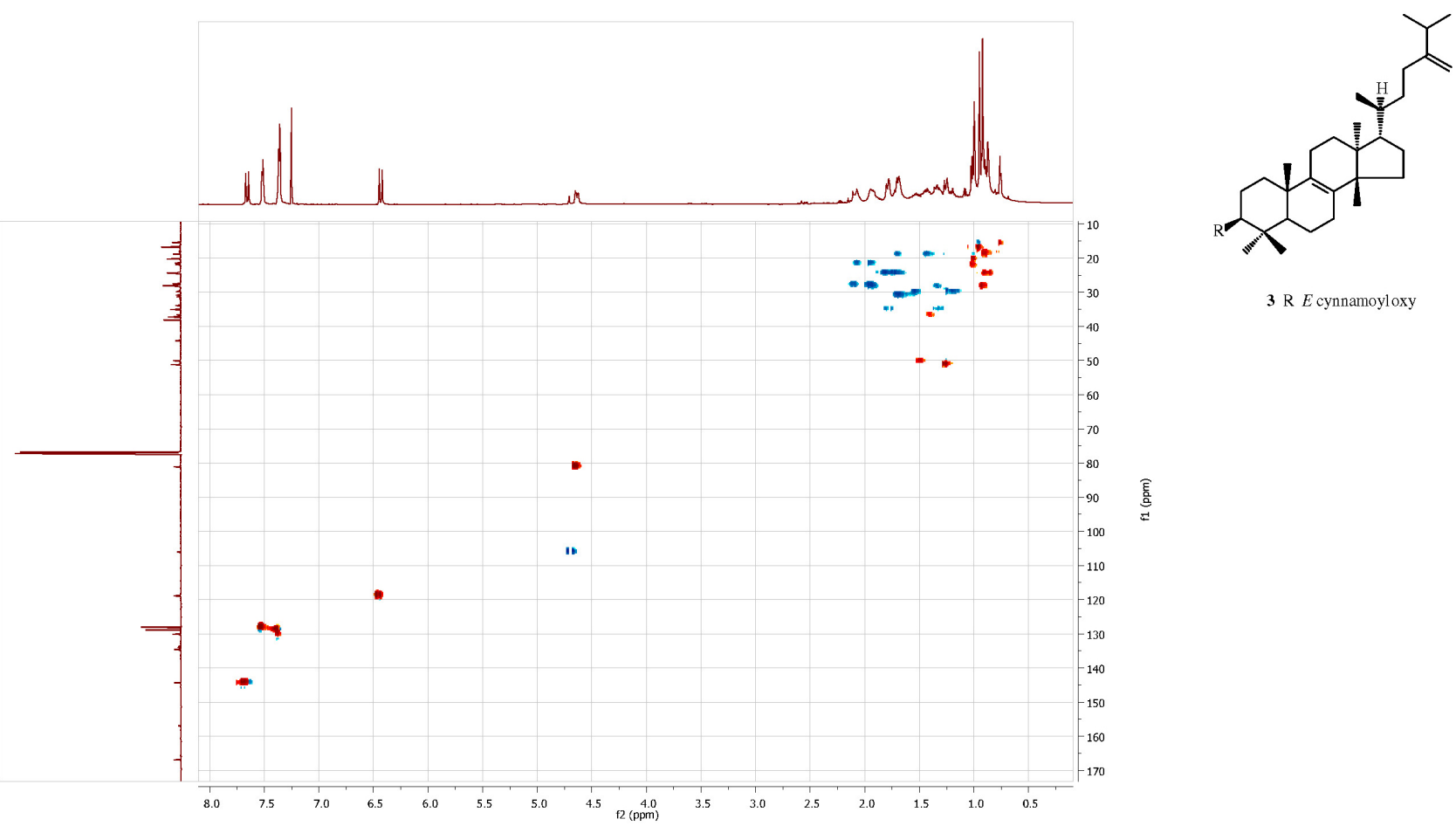

3 R E cynnamoyloxy

Figure S4. $\mathrm{HSQC}$ spectrum $\left(600 \mathrm{MHz}, \mathrm{CDCl}_{3}\right)$ of compound 3 . 


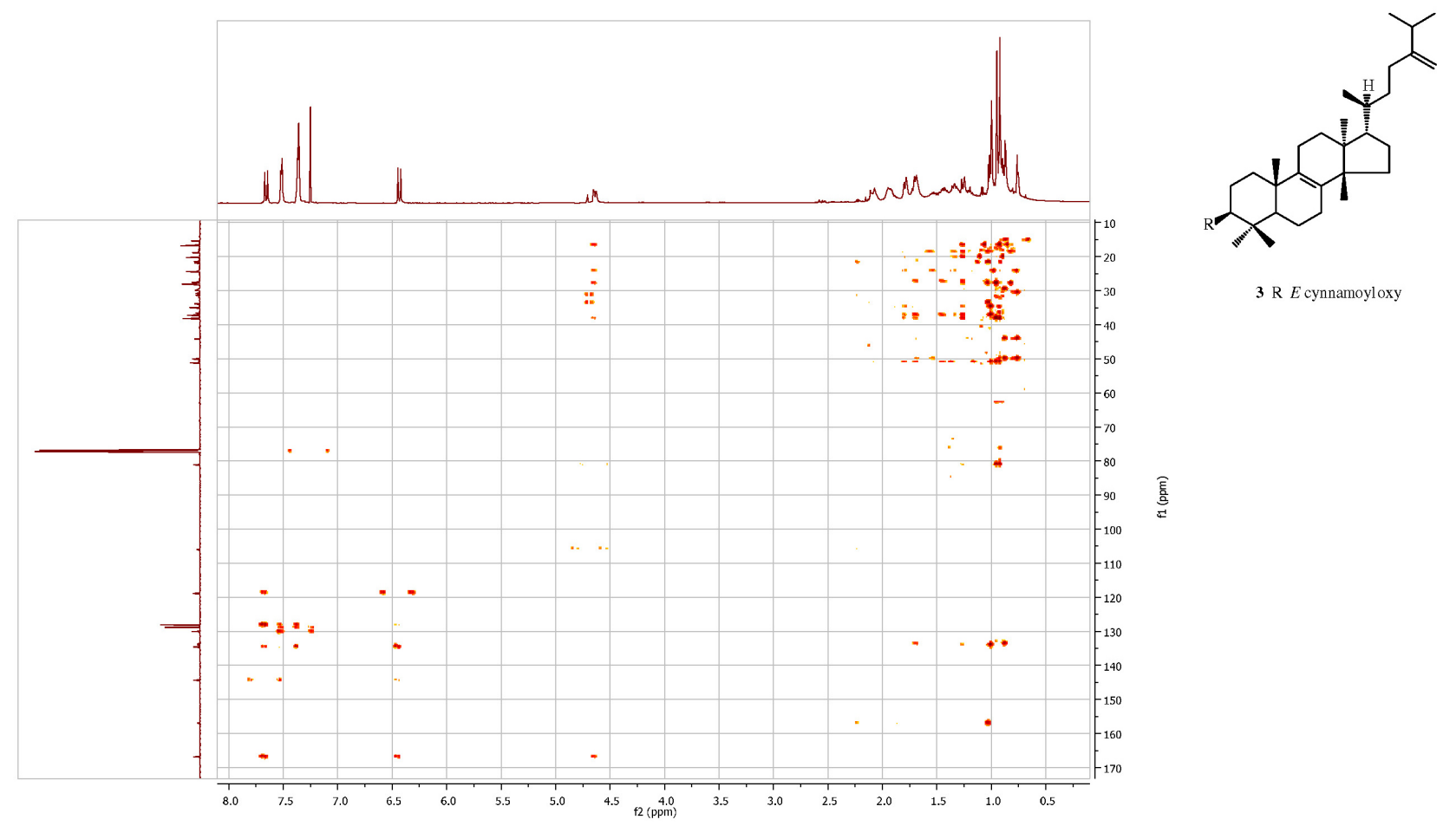

Figure S5. $\mathrm{HMBC}$ spectrum (600 $\mathrm{MHz}, \mathrm{CDCl}_{3}$ ) of compound 3.

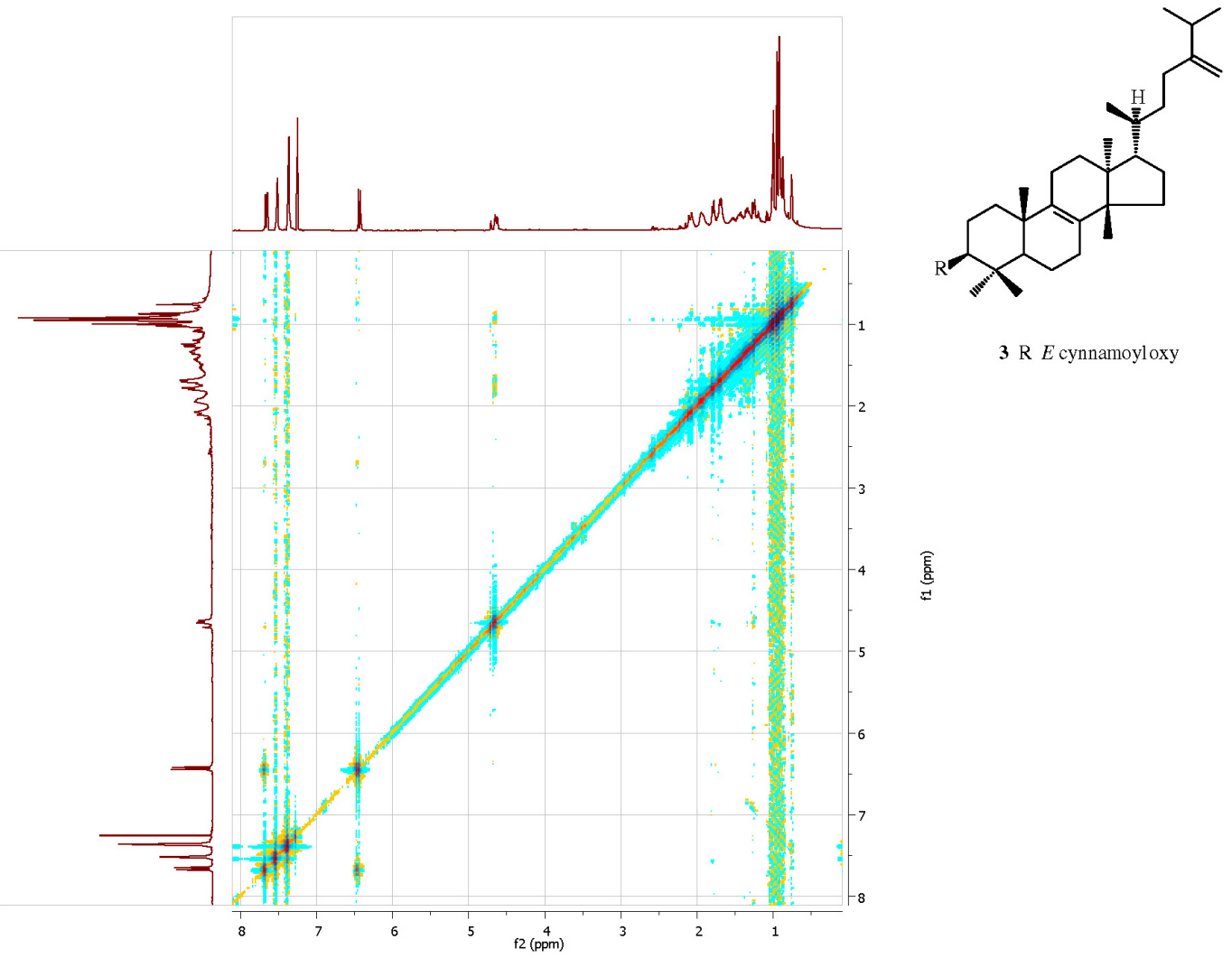

Figure S6. NOESY spectrum (600 MHz, $\left.\mathrm{CDCl}_{3}\right)$ of compound 3 . 